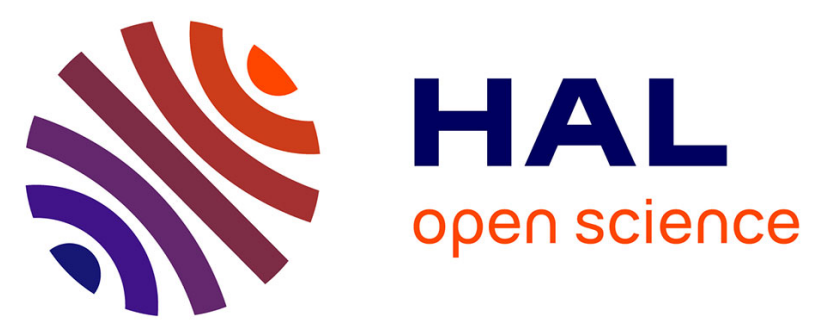

\title{
Review of "Getting the Picture: The Visual Culture of the News" edited by Jason E. Hill and Vanessa R. Schwartz
}

François Brunet

\section{- To cite this version:}

François Brunet. Review of "Getting the Picture: The Visual Culture of the News" edited by Jason E. Hill and Vanessa R. Schwartz. Visual Studies, 2017, Visual Studies, 32 (2), pp.190-191. 10.1080/1472586X.2016.1274194 . hal-01539046

\section{HAL Id: hal-01539046 \\ https: / hal-univ-paris.archives-ouvertes.fr/hal-01539046}

Submitted on 14 Jun 2017

HAL is a multi-disciplinary open access archive for the deposit and dissemination of scientific research documents, whether they are published or not. The documents may come from teaching and research institutions in France or abroad, or from public or private research centers.
L'archive ouverte pluridisciplinaire HAL, est destinée au dépôt et à la diffusion de documents scientifiques de niveau recherche, publiés ou non, émanant des établissements d'enseignement et de recherche français ou étrangers, des laboratoires publics ou privés. 
"This is an Accepted Manuscript of an article published by Taylor \& Francis in Visual Studies on 12 January 2017, available online:

http://www.tandfonline.com/10.1080/1472586X.2016.1274194

http://dx.doi.org/10.1080/1472586X.2016.1274194

\section{Getting the Picture: The Visual Culture of the News}

edited by Jason E. Hill and Vanessa R. Schwartz

London: Bloomsbury, 2015, 300 pages

ISBN: 978-1-4725-2649-6 (paperback) Price $\$ 39.95$

Reviewed by François Brunet, Université Paris Diderot / Institut Universitaire de France

In the second decade of the twenty-first century it is no longer news that the news, and the news picture particularly, are 'formed and selected rather than merely transcribed' (2). This quote comes from Jason Hill's and Vanessa Schwartz's gloss of a mid-19 ${ }^{\text {th }}$-century painting of a sea battle, or rather of a news illustrator sketching the battle from a small vessel in the foreground, that serves as opening illustration for the introductory essay to Getting the Picture. If the Dutch painter J. De Hoy back in 1845 pointedly drew attention 'to the always historically specific means by which any artist figures the world outside the frame',' by 2015 the questions "What is a news picture and how does it work?" (2) cannot be answered, or even asked, in the same terms in which they were framed in the late $19^{\text {th }}$ or the mid- $20^{\text {th }}$ century, whether by professional news editors, cultural historians, or even formalist art historians. $21^{\text {st }}$-century academic culture, and arguably a broader, increasingly reflexive, urban visual culture, readily agrees that news pictures 'are predicated upon the difficult idea and desire that a picture's immediacy and ability to condense and concretize knowledge might offer its viewer a privileged relationship to an otherwise unknowable world' (2). The idea's "naturalization" (2) and the need to "denaturalize" it, particularly in its privileged association with photography, have been not only fully recognized but very substantially explored by dozens of commentators, since at least the 1970s. 
Thus Getting the Picture does not invent the topic of the "visual culture of the news', and the editors make no such claim. What it certainly does is to give this topic a distinctive appellation (while affiliating it with visual studies) and, more importantly, a very extensive treatment, if not an exhaustive survey, which is perhaps best characterized by its reflexive stance. Getting the Picture can be read as "an essential scholarly compendium" (in the words of its reviewer, W.J.T. Mitchell, back cover), in the sense that it is erudite and authoritative, but also in that it brings together a specialized community to lay open to the larger scholarly community its interrogations about the state and history of its field. The book, however, is not a mere discussion of pre-existing scholarship on the topic. Its interdisciplinary, international, and very inter-generational array of fifty-some contributors-including a few scholars with nonNorth American affiliations - introduces much recent and current research, which the editors manage adeptly to articulate and weave into a richly layered argument, involving a complex series of choices, claims, and caveats. One of the most obvious, and necessary, of these choices is the full immersion of the book's discourse into present-day digital visual culture and its debates, although by far most of the images and publications discussed are pre-digital. One of the most compelling and convincing is Hill's and Schwartz's plea to quit the overbearing, selfconsciously high-brow, Frankfurt School-like or Modernist "assumption of the naïve consumer of new pictures ...subdued by an industry responsible for providing those pictures'. Hill and Schwartz also argue that" "newsreaders have been more sharp-eyed than they have been credited with" and that "audience savvy" has always been a factor of production (9). The book's structure indeed testifies to a purpose that values diversity, plurality of 'meaning' and its construction, and brevity, over linear, monolithic, or even merely narrative models. I can only give a brief sketch here.

The first of the two main sections of the book, "Big Pictures",' is composed of 26 short analyses, in chronological succession, of single "news pictures" that for the most part are

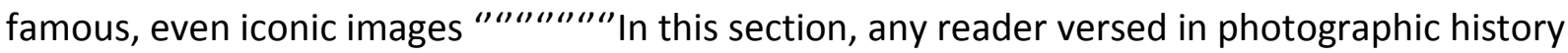
and visual culture surveys will recognize much familiar terrain, expanded, revisited, or recontextualized, rather than discovered (although the book does offer several inventions, such as Schwartz's discussion of Ernst Haas's reportages for Life in "New York in Color, 1953"). The 
same reflexive approach carries over to the second and larger section of the book, entitled "Rethinking the History of News Pictures',' itself divided into five chapters ('News Pictures and Press Genres,' 'News Picture Media,' 'New Picture Time,' 'Speaking of News Pictures,' and 'News Picture Connoisseurship,'), each of which comprises four or five longer essays on more or less familiar subthemes (e.g. for 'Press Genres:' fashion, celebrity, war, sports, crime). This extremely rich section best illustrates the interdisciplinary and multipolar orientation of the collection, as well as its often remarkable conceptual rigor (for instance in Hill's essay on the complex temporalities at work in the production and diffusion of a 1910 news photograph of the shooting of NYC Mayor William Gaynor, 'Snap-Shot: After Bullet Hit Gaynor,' in opposition to the apparently simple notion of the 'snapshot' and its formal consecration as 'great document' in Beaumont Newhall's 1937-38 treatment of news photography). By the same token it confirms that Getting the Picture is a 'second view,' a reflexive critical survey, a revision rather than an exploration of a 'visual culture of the news' that, as we realize in reading, is already so familiar not just as ambient 'iconic' imagery but as constructed history.

This remark leads me to a final observation, or interrogation, precisely about the kind of history that this volume belongs to, or dialogues with, since the editors, in opting for the label 'visual culture,' seem to wish to avoid a narrower categorization of their purpose as (visual or other) history. Art history is the predominant background among the authors gathered here, as well as the primary operative disciplinary context of the essays. This might seem like a restriction to those who expect a visual history of the news to give more prominence to technological, economic, or sociological perspectives (which, however, are all duly represented in the second section especially, and in several cases enriched by forays into their respective histories of ideas). Perhaps the project's most strategic choice is its focus not only on still images, more specifically photographs (though other print and electronic media and their histories from about 1840 to the present are also featured), but on single 'news pictures' and their (hi)stories. Not only are moving images only present in the form of stills; but there are few attempts, in the volume as a whole, to consider larger ensembles, archival contexts, and even relatively few examinations of magazine layouts, contact sheets, and other larger visual contexts. The book's very focus on photography, and on photographs that in many cases, as 
mentioned, have previously been distinguished by more formalist histories, is consistent with this predominant 'art historical' approach. But this, I must add, is nonetheless art history at its best, written by many of the best in the field; an art history that enthusiastically and successfully espouses the full, potentially limitless spectrum of its $21^{\text {st }}$-century object field, while firmly holding to a faith in the aesthetic appeal of images as the primary functional motif of their social, economic, and political lives. That the history of photography and even of the pictorial print media cannot possibly claim to represent the whole of 'the visual culture of the news' is obvious. That the history of photography, in its full critical and historiographical complexity, is the best, if not the only possible, vantage point from which to start, augment, and revise our approaches of this visual culture of the news is what Getting the Picture very ably demonstrates. 